\title{
PREFACE
}

This new volume dedicated to the $60^{\text {th }}$ Anniversary of the establishment of the MUST, and to the $80^{\text {th }}$ Anniversary of the Mongolian Geological Survey. The volume contains papers discussing bacterial paleontology, neotectonic, petrogenesis, geochronology, mineral resources and society news etc. There are authors from different geographic localities such as Mongolia, Japan, China, Australia, Russia and Czech.

Our editorial board members and invited reviewers have worked hardly to ensure the quality of the submitted manuscripts good. We are sure the published papers will have a significant contribution to the Mongolian Geology.

Dear geologists, researchers, authors and readers, we invite you to publish your new research findings in the Mongolian Geoscientist open access journal and distribute internationally.

The journal Editorial board members and Associate editors will always work to improve the quality, efficiency and standing of the journal.

\section{Thank you to our Editors and Invited Reviewers}

We sincerely thank to the journal editorial team and invited editors of our open access volumes No 47 , 48 and 49. They are the people who make an internationally peer reviewed, open access journal. Reviewer's helpful and constructive comments led to improvement in the each manuscript and successful volumes.

\section{Editors:}

Bayasgalan Amgalan

Altanzul Baasandorj

Munkhtsengel Baatar

Erdenetsogt Bat-Orshikh

Batkhishig Bayaraa

Chris Osterman

Jaroslav Dostal

Tsogtbaatar Khishigjav

Buyankhishig Nemer

Gerel Ochir

Tumurtogoo Onongo

Tseedulam Khuut

Per Michaelsen

Riemar Seltmann

Takahashi Yuhei

Tsuchiya Noriyoshi
Invited reviewers:

Chimedtseren Anaad

Gantulga Bayasgalan

Uyanga Bold

Bolormaa Byambatseren

Bolorchuluun Chogsom

Jargal Chultemsuren

Laicheng Miao

Mingshua Zhu

Pavel Hanzl

Khishigsuren Sodnom

Narantsetseg Tserendash

\section{Editor-in-Chief}

Batkhishig Bayaraa

Associate editors:

Munkhtsengel Baatar

Altanzul Baasandorj

Tseedulam Khuut

$\underline{\text { mongoliangeoscientist } @ \text { must.edu.mn }}$ 